\title{
Analysis of estuarine flood levels based on numerical modelling. The Douro river estuary case study
}

\author{
Stênio Venâncio' \\ José Luís Pinho" \\ José Manuel VieirallI \\ Paulo Avilez-Valente ${ }^{\mathrm{IV}}$ \\ Isabel Iglesias ${ }^{\vee}$
}

\begin{abstract}
Estuarine hydrodynamics present intermittent and complex circulation patterns. In this context, from the point of view of the coastal management associated with flood risks in riverine areas, numerical models allow predicting scenarios under specific hypotheses. This work simulates flood events occurring in the Douro river estuary recurring to numerical modelling tools. This estuary, located in the northern region of Portugal, periodically suffered severe flooding, with the associated losses and damages for the local protected landscape areas and hydraulic structures. The occurrence of these events justify the importance of a complete characterization of the areas that present risk of inundation and how they can be affected. A 2D-horizontal numerical model implemented with the Delft3D software was developed for this estuarine region including also the adjacent coastal zone. Available in-situ data were used for model calibration and validation processes. The obtained results are consistent with the in-situ measured water levels, allowing to understand the dynamics of the estuary during flood events. The robustness of the implemented numerical model allows to anticipate flood scenarios effects and associated water levels. The simulations results can then be used for sustainable management of this estuarine zone that presents high social, economic and environmental values.
\end{abstract}

Keywords: numerical models; estuary; Douro river; floods; Delft3D

\footnotetext{
'Associate Professor, Department of Civil Engineering, Federal University of the Triângulo Mineiro, Uberaba-MG, Brazil and Center of the Territory, Environment and Construction (CTAC), University of Minho, Braga, Portugal. stenio.venancio@uftm.edu.br

" Associate Professor, Center of the Territory, Environment and Construction (CTAC), University of Minho, Braga, Portugal. jpinho@civil.uminho.pt

III Full Professor, Center of the Territory, Environment and Construction (CTAC), University of Minho, Braga, Portugal. jvieira@civil.uminho.pt

${ }^{\text {IV }}$ Assistant Professor, Department of Civil Engineering, University of Porto, Porto, Portugal and Interdisciplinary Centre of Marine and Environmental Research (CIIMAR), University of Porto, Porto, Portugal. pvalente@fe.up.pt

$\checkmark$ Assistant Researcher, Interdisciplinary Centre of Marine and Environmental Research (CIIMAR), University of Porto, Porto, Portugal. iiglesias@ciimar.up.pt
} 


\section{Introduction}

The positive impact of the environmental equilibrium on the sustainable management of estuaries makes these environments globally recognized, including their economic value, motivating diverse researches related to the species that inhabit it, water quality (aquatic life and recreation), exploration of waterways and power generation. Traditionally, for estuaries and for various river and sea systems throughout the world, behavioral analyzes and their evolution focus on the study of specific parameters, whether physical, chemical and/or biological, under the effect of the local hydrodynamics, with mathematical models of extrapolation. The large bottleneck of this method occurs due to the significant number of required field campaigns, in order to minimize errors in this process, which can be made unfeasible by the question of time and number of samples and by the high costs involved. In this sense, the association of field data to computational simulations has revealed a gain in time, and consequently monetary, anticipating scenarios and realistically forecasting preventive and scheduled maintenance actions, supporting the decisionmaking process. Although hydroinformatics is a relatively recent scientific field, many researches have been developed, combining computer tools with environmental concepts and models, allowing diagnosis and information for medium and long term management, even in situations where the objective is to determine the flood levels in complex hydrodynamic systems, as is the case with estuaries (Bastos et al., 2016).

This knowledge, which integrates hydrodynamic behavior, is a valuable tool for decision-making process of these environments, including mitigation measures. It can be applied in both, flood events or low flow conditions. Flooding scenarios are harmful events that have associated an important risk in terms of population, human settlements, erosion processes, structural damages, environment and economic losses. Low flow scenarios should also be characterized to depict the siltation processes and the increase of the water residence time that can have an important effect over the sediments, pollutants and salt distribution. In this sense, the work of Hu et al. (2009) should be remarked, particularly for its developments in the modeling 
of hydrodynamics and sediment transport of the Yangtze Estuary - China, for the flood situation (including winds and waves due to typhoons). Despite the limitations of modeling, highlighted by the authors, and related to scatter of wind and bedload data, the results of measured water levels had a good correlation with the data simulated by the model. Similar analysis, with the same numerical modeling approach, can be seen in Stoschek and Zimmermann (2006), in the Weser River Estuary - Germany, Kwo et al. (2007), in the York River Estuary - USA, Ganju and Schoellhamer (2009), in the Suisun Bay estuary - USA and Kuang et al. (2013) in the Yangtze River estuary - China, where the authors conclude that the results of simulated water levels have a good approximation with the data monitored in the field. Works of this nature accurately reproduce, as exemplified above, water levels, tidal propagation, flow velocities and discharges, helping to properly represent the hydrodynamical patterns of these regions. In this context, the implementation of numerical modeling suites, which solve the governing equations of conservation of mass and momentum, allows the analysis of complex hydraulic systems, such as estuaries, solving the physical questions of these systems.

The present study has the specific objective of the implementation, calibration and validation of a 2D hydrodynamic numerical model for the Douro estuary, Portugal, using historical water levels and flood records. This model should constitute a complementary computational tool for the analysis of scenarios of flood events, acting as support for the definition of regularized river flows as a function of maximum water levels in the estuary. Historical flooding in the estuary affects, more incisively, the shores of urban areas. In this urban area, the cross-section of the estuary has no adjacent plains, with concentrated floods, mainly affecting the trade located there, with tourism and economic impacts. With the gradual decrease of river flow into the estuarine region due to dams construction for hydropower production and river flow regularization, and the construction of ocean defenses in the estuarine mouth, , a growth (upstream) of the Cabedelo sand spit is observed (Bastos et al 2012). Analysis of the influence of this spit of sand for the elevation of the flood levels of the estuary, represents a pressing demand of this process of study. 
Studies already done in the estuary of the Douro river presented results obtained from in situ monitoring techniques and focused on the ecological aspects, pollution impact and morphodynamic evolution (Azevedo et al., 2008 and 2010; Araújo et al., 2013; Bastos et al. 2012; Magalhães et al. 2001; Mendes et al. 2010; Mucha et al. 2003 e 2004; Portela 2008). Nevertheless, there is a lack of previous studies focused on the characterization of floods dynamics and effects in this estuarine region.

In this work, a set of numerical simulations were performed to represent the state of the estuarine region under historical flood events. The numerical model implemented was based in the Delft3D model suite. This widely used modelling suite can carry out simulations that represent the effect of flows, sediment transports, waves, water quality, morphological developments and ecological processes in coastal, river and estuarine areas. The suitability of the Delft3D modelling suite in represent the effects of floods in estuarine regions was demonstrated by previous studies. Delft 3D was selected to represent the hydrodynamics and salinity configuration of estuarine regions (Santosa et al., 2015), to forecast the impact of channel deepening and dredging on estuarine sediment concentration (Van Maren et al., 2015) and to perform risk assessment scenarios related with floods in coastal areas (Gomes et al., 2015) and tsunami propagation (Van Ven et al., 2015). This modelling suite is also adequate to represent long-term hydrodynamic studies considering climate change scenarios (Abubaker and Walid, 2015) and to develop applications for natural hydraulic systems (Harcourt-Baldwin and Diedericks, 2006; Van Maren, 2007; Bouma et al., 2007; Tonnon et al., 2007; Allard et al., 2008; Hu et al., 2009).Risk assessment of flooding in coastal areas, with Delft3D, can be seen in the work of Gomes et al. (2015), for the area of The Battery, New York, situated in New York Harbor. Van Maren et al. (2015) studied the impact of channel deepening and dredging on estuarine sediment concentration, in EMS estuary, located between the Netherlands and Germany. The model, according to the authors, satisfactorily reproduces observed water levels, velocity, sediment concentration and port deposition in the estuary. Santosa et al. (2015) evaluated the hydrodynamics and 
salinity in the Columbia estuary, which is situated in Oregon, United States. The preconfigured model was calibrated based on 15 measurement stations that are spread along the estuary, and showed good agreement between measured and simulated water level, velocity and salinity. For implementation of a regional Tsunami Early Warning System (EWS) in Sumatra island in Indonesia, a set of detailed and accurate tsunami propagation and flooding models using Delft3D were developed in the work of Van Ven et al. (2015). The purpose of the models was not only to reproduce the 2004 Indian Ocean tsunami, but also to determine tsunami flood hazard maps with different return periods. The system has been successfully installed and tested in the last two years at national and regional emergency coordination centres, National Agency for Meteorology, Climatology and Geophysics (BMKG) and at Tsunami Disaster Mitigation Research Centre (TDMRC) in Banda Aceh. In hydrodynamic studies of long-term, climate change scenarios, the work of Abubaker and Walid (2015) performs numerical forecast for the year 2080, of the Arabian Gulf. The long term impacts of climate change on hydrodynamics were evaluated using the current capacity and production rates of coastal desalination, power, and refinery plants. Work involving applications Delft3D in natural hydraulic systems are also described e.g. Harcourt-Baldwin and Diedericks (2006), Van Maren (2007), Bouma et al. (2007), Tonnon et al. (2007), Allard et al. (2008) and Hu et al. (2009). The water levels modelled results, obtained for different scenarios, demonstrated robustness and accuracy to reproduce this complex phenomenon. This computational tool, therefore, associated to monitoring campaigns, could constitute an instrument of estuary management, allowing, with lower costs, to anticipate future hydrodynamic scenarios with confidence.

\section{Material and Methods}

\subsection{Study Area}

The Douro River is born in Spanish territory and flows into the Atlantic Ocean in Portugal, bordered on the right by the city of Porto and on the left bank by Vila Nova 
de Gaia. The estuary, which is the object of this study, has an extension of approximately $22 \mathrm{~km}$, starting at the Crestuma hydroelectric complex, which regulates the river flow. According to Azevedo et al. (2010), the river flow can reach $13.000 \mathrm{~m}^{3} / \mathrm{s}$ in certain situations. However, the seasonality observed in winter and summer periods, causes a significant variation of the river flow according to the precipitation patterns in this area (Gómez-Gesteira et al., 2011), the highest and lowest intensity flows occur from October to May and from July to September, respectively. This variation, according to Vieira and Bordalo (2000), causes that the residence time in the estuary has an estimated permanence rate between $8 \mathrm{~h}$ and 2 weeks depending on the river flow and tide conditions.

The morphodynamic evolution of the sand spit located at the estuarine mouth has been routinely monitored, revealing an increase in the sand spit area and volume since the breakwater construction (Bastos et al., 2012). The variable size and shape of the sandbar caused frequent discomfort in the past for navigation activities, affecting the width and depth of the navigation channel, so to improve navigation safety, between 2004 and 2008 a breakwater was built to stabilize the shoal. The changes in the hydrodynamic patters due to the breakwater construction seems to deal into accretion processes that are producing an instability in the southeastern part of the Cabedelo sand spit that can represent a threat to the existing local nature reserve. The location and configuration of the Douro river estuary from the upstream section at Crestuma dam to the river mouth at the Atlantic Ocean is represented in the Figure 1(a). 
Figure 1- (a) Location of the Douro river estuary. (b) Location of monitoring stations

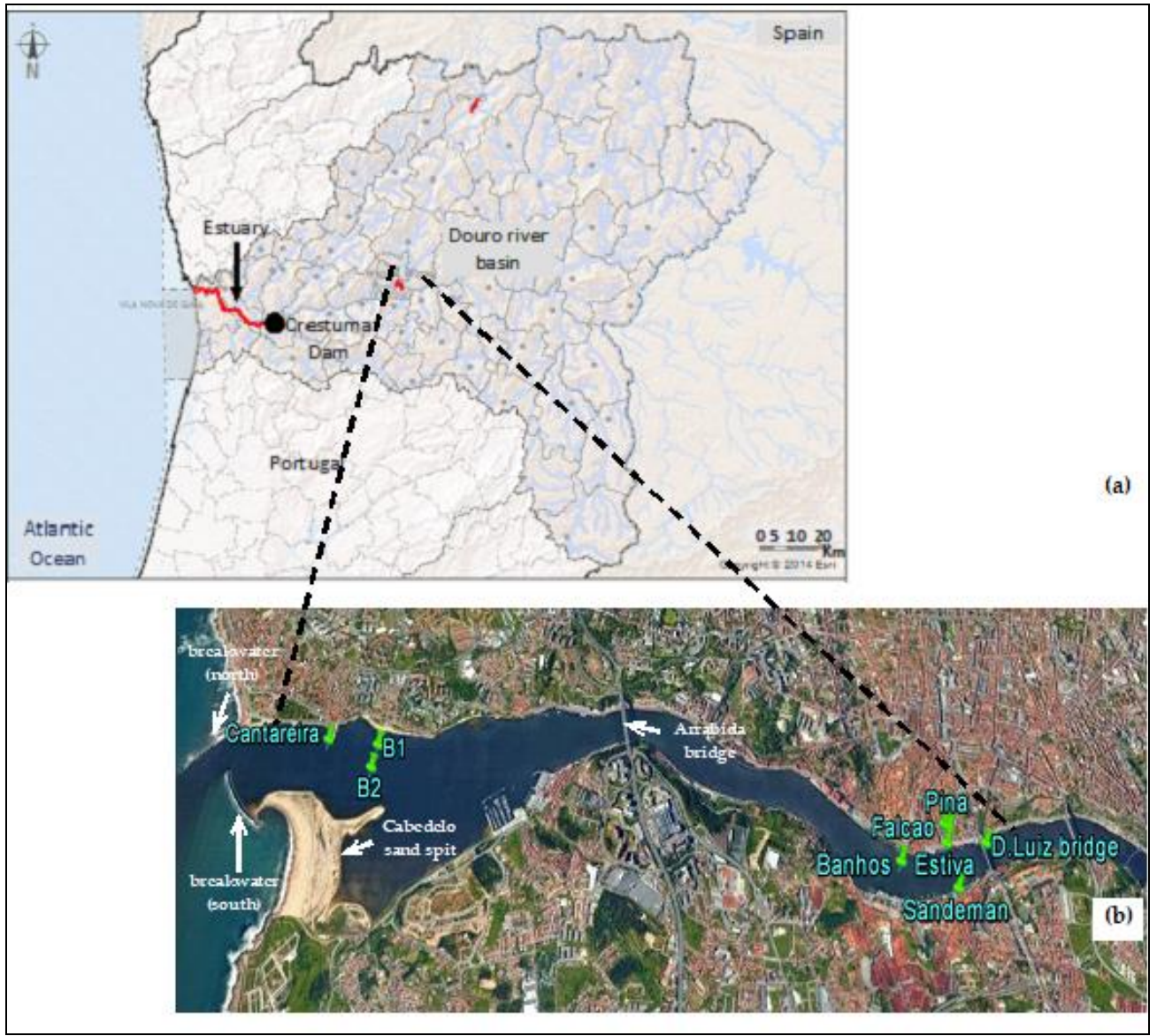

Source: APA, 2015 and Google Earth satellite image, modified by the authors

\subsection{Field Data}

From the $5^{\text {th }}$ September to $5^{\text {th }}$ October of 1994, a hydromorphological campaign was carried out at the Douro river estuary, by the Portuguese Hydrographic Institute (IH) under the responsibility of the Douro and Leixões Port Authority (ADPL). During this campaign, different variables were measured: water levels, currents, sediment transport (suspended and bedload), particle size and sediment characterization, as well as bathymetry of the entire estuary.

Water level data for the 1994 campaign were collected at Cais da Estiva and Cantareira monitoring stations and currents velocity data were measured at monitoring stations B1 and B2. These field data provided by the Portuguese Hydrographic Institute $(\mathrm{IH})$ was carefully chosen to validate the numerical model implemented in this study. The historical flood data selected correspond to three flood events: 21/02/1966, 09/01/1996 and 10-11/01/2016. Floods peak discharges, 
imposed in the numerical model at the upstream open boundary (Crestuma dam), were obtained from Pardé (1966), for the 1966 flood, and provided by Energia de Portugal (EDP) for the other flood events. The oceanic tides (downstream boundary) were provided by $\mathrm{IH}$. Water levels simulated by the model were compared to the flood marks identified, in loco, in the SANDEMAN winery (1966 and 1996 floods), PINA furniture store (1966 and 1996 floods) and D. Luís bridge (1966 flood). Also, the tide gauge station data at Cais dos Banhos was used to asses the water levels evolution during the 2016 flood. For the 1966 and 1996 floods, the maximum flow discharges values considered at Crestuma dam were $14.600 \mathrm{~m}^{3} / \mathrm{s}$ and $10.500 \mathrm{~m}^{3} / \mathrm{s}$, respectively. For the 2016 flood, EDP provided the hourly discharges recorded between 10 and $11 / 01 / 2016$, with a peak discharge of $7.200 \mathrm{~m}^{3} / \mathrm{s}$. The location of the monitoring stations and the measured points for the flood levels are shown in Figure 1 (b).

\subsection{Numerical Model}

Delft3D is an open source modeling suite able to accurately represent hydrodynamics, sediment transport, morphology and water quality for fluvial, estuarine and coastal environments. This software, developed by Deltares, consists of several modules that can interact with each other. Delft3D-FLOW (Delft3D-FLOW, 2011), the core of these modules, is a multidimensional (2D or 3D) hydrodynamic (and sediment transport) simulation software that solves the Navier-Stokes equations for an incompressible fluid under the concept of shallow water and the assumptions of Boussinesq approximation. This module also computes the sediment transport and updates the morphology simultaneously with the flow (Lesser et al., 2004). The twodimensional hydrodynamic model constructed in this work uses an orthogonal grid with a total number of 13.440 cells, necessary and sufficient to cover the entire estuary area from the Crestuma dam (upstream boundary) to the Atlantic Ocean (downstream boundary).

At the upstream open boundary, the Crestuma dam outflows were considered and time series of measured hourly discharges were adopted. At the downstream open boundary, the ocean tide levels time series were implemented 
for each scenario. The bathymetric data considered to build the orthogonal grid and the modeled region are represented in Figure 2. A calibration procedure was performed and the model results were compared with the 1994 field campaign available data (water levels and average current velocities) and also with the water levels obtained for the 1966, 1996 and 2016 floods, using for both kind of simulations the same grid (1994). All scenarios and problems analyzed are shown in Table 1.

Table 1 - Modeling scenarios for Delft3D

\begin{tabular}{|c|c|c|c|c|c|c|}
\hline analyzed problem & scenarios & $\begin{array}{c}\text { field data } \\
\text { (date) }\end{array}$ & tide & $\begin{array}{l}\text { flow } \\
\left(\mathrm{m}^{3} / \mathrm{s}\right)\end{array}$ & $\begin{array}{c}\text { turbulence } \\
\text { model }\end{array}$ & $\begin{array}{l}\text { simulation } \\
\text { time (day) }\end{array}$ \\
\hline $\begin{array}{c}1 \text { - Hydrodynamics/validation (flow, } \\
\text { water level, velocity) }\end{array}$ & $\begin{array}{l}\text { hydrometric } \\
\text { campaign }\end{array}$ & $\begin{array}{c}11 / 09 \text { à } \\
05 / 10 / 1994\end{array}$ & historical & horary & $2 \mathrm{DH}$ & 18 \\
\hline \multirow{2}{*}{$\begin{array}{c}2 \text { - Hydrodinamic/floods (flow/historic } \\
\text { water levels) }\end{array}$} & 1 & 21/02/1966 & \multirow{2}{*}{ high tide } & 14600 & \multirow{2}{*}{$2 \mathrm{DH}$} & 1 \\
\hline & 2 & 09/01/1996 & & 10500 & & 1 \\
\hline \multirow[t]{2}{*}{3 - Hydrodinamic/floods (tide) } & 1 & 21/02/1966 & \multirow{2}{*}{ high tide / low tide } & 14600 & \multirow{2}{*}{$2 \mathrm{DH}$} & 1 \\
\hline & 2 & 09/01/1996 & & 10500 & & 1 \\
\hline \multirow[t]{3}{*}{4 - Hydrodinamic/floods (breakwater) } & 1 & $21 / 02 / 1966$ & \multirow{2}{*}{ high tide } & 14600 & \multirow{3}{*}{$2 \mathrm{DH}$} & 1 \\
\hline & 2 & 09/01/1996 & & 10500 & & 1 \\
\hline & 3 & $10-11 / 01 / 2016$ & historical & horary & & 3 \\
\hline
\end{tabular}

The flood events were simulated considering the presence and absence of the breakwater. The breakwaters were added in the numerical grid as solid walls, allowing the representation of the effects that these structures have on the estuarine dynamics during flood events. In order to validate the numerical solutions, the model parameters related with bottom friction and turbulence were calibrated based on a sensitivity sound analysis and through comparison with the available field data, related to water levels and currents velocities obtained for the period between 11/09 and 05/10/1994 (analyzed problem 1). The selected values were a Manning roughness coefficient of $0,039 \mathrm{~s} \cdot \mathrm{m}^{-1 / 3}$ and $a$ horizontal eddy diffusion coefficient of $1 \mathrm{~m}^{2} / \mathrm{s}$. These coefficients were maintained for all the flood scenarios. The numerical simulation of historical floods in the Douro river was analyzed (problem 2) for maximum flows (of each flood event) and two different tide levels: high and low tide levels (problem 3). An 
assessment of the influence of the breakwaters (problem 4) on some flood events is also done.

Figure 2 - Numerical model of the Douro river estuary, implemented in Delft3D, with the 1994 estuary bathymetry (a); estuarine mouth - without breakwaters (b); with breakwaters (c)
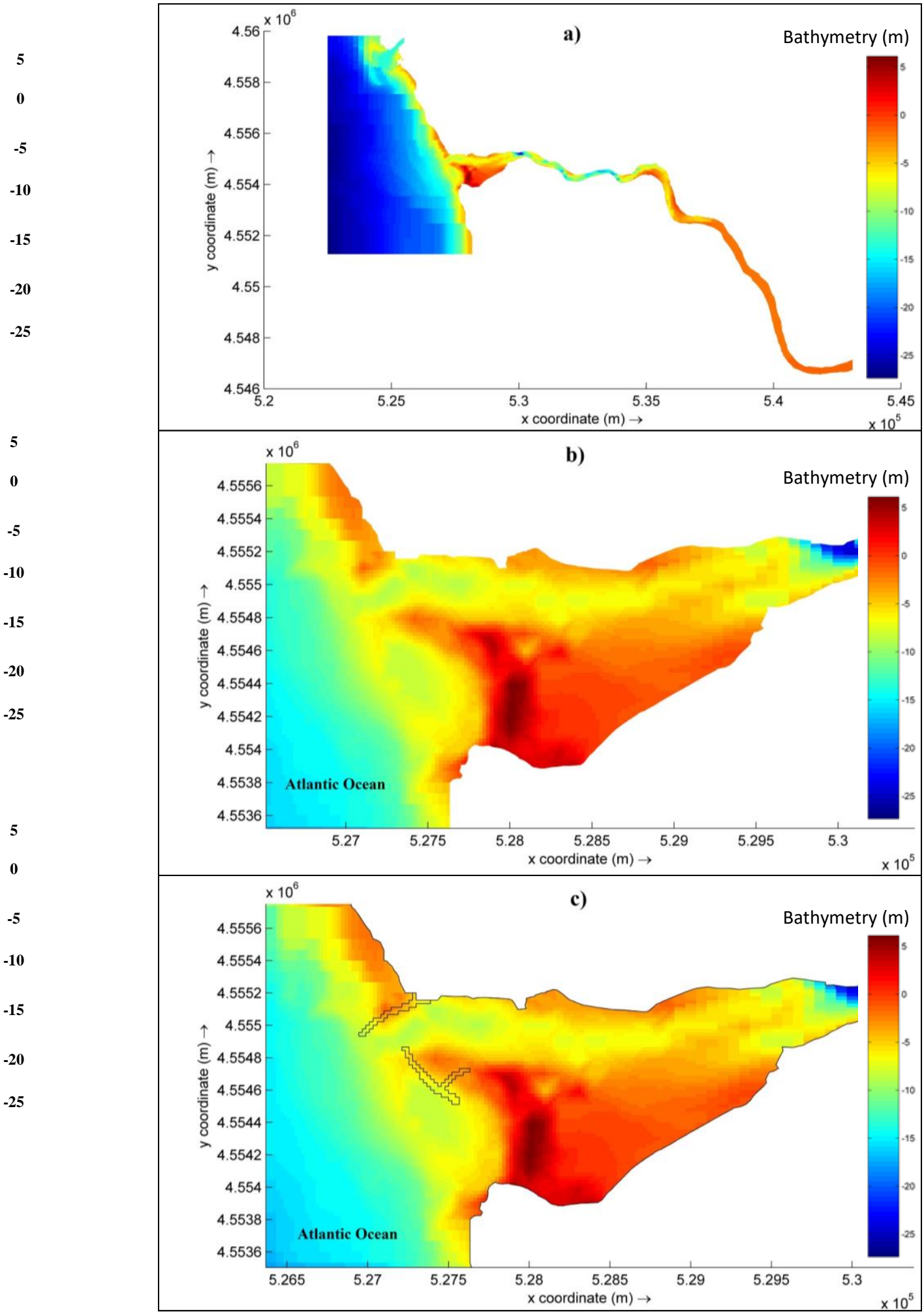

Source: authors 
To assess the model performance in terms of measured and simulated water and velocity data related to problem 1 (Table 1 ), the following metrics were selected: Nash-Sutcliffe (NS) efficiency model, correlation coefficient (R2), root-meansquare error (RMSE) and the mean absolute error (MAE).

\section{Results}

The comparison between the modelled values and measured data at Estiva and Cantareira monitoring stations pointed to an almost perfect correlation as shown in Figure 3.

Figure 3 - Measured and modelled water levels at Estiva and Cantareira control points
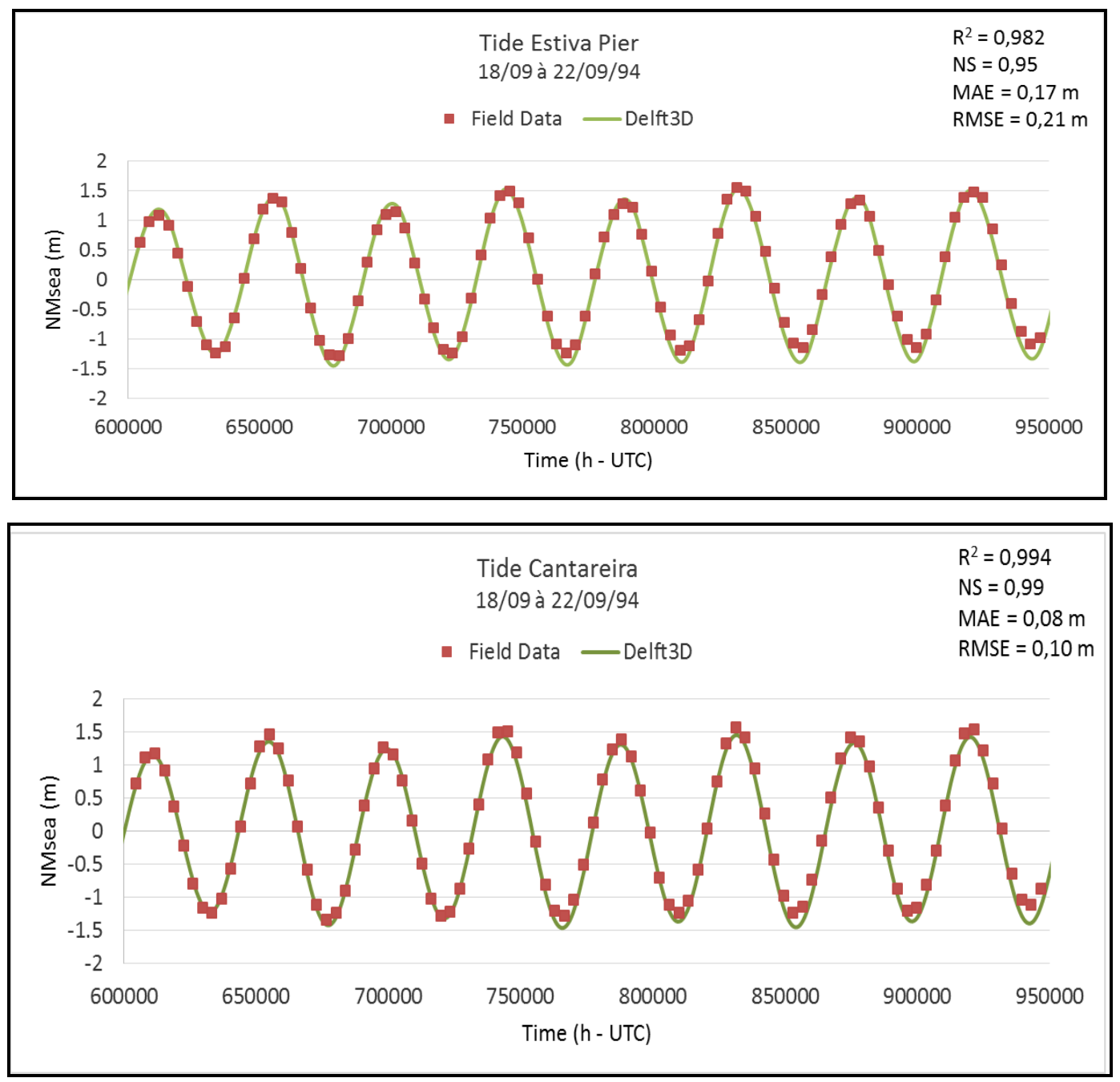

Source: authors, numerical model output 
For the comparison of the measured and simulated velocities, and considering that a 2DH model approach was followed, only the vertical average currents were compared. The results for stations B1 and B2 are shown in Figure 4. Despite the vertical averages considered, there is also a close correlation between the simulation results and the in-situ measurements. For B1 station, located at the northern margin of the estuary where the slope profile is relatively straight and uniform, the correlation between measured velocities and simulated ones was 0,947. For B2 station, closer to the Cabedelo sand spit on the southern margin, a greater divergence between the measured and the simulated currents was found, with a correlation of 0,832 . The enlargement that occurs in the southern margin with significant depth variation leads to a more diffuse flow pattern. Despite the divergence in $\mathrm{B} 2$, the comparative results can be considered as satisfactory in terms of water levels and currents, allowing the definition of other scenarios to characterize the water levels profiles and the currents behavior along the estuary. In the sensitivity tests during the calibration processes, it was possible to verify that for relatively small river flows in the estuary, the average roughness, viscosity and turbulent diffusivity have a small effect over the simulated water levels. When flood events flows above $13000 \mathrm{~m}^{3} / \mathrm{s}$ are implemented in the numerical model, there was an underestimation of the simulated water levels in relation to the measured values. For situations tested with different bathymetries, it is noted that elevations in the bottom, which occur mainly at the mouth of the estuary, may slightly alter upstream water levels and modify the periods of tidal propagation into the estuary. For situations tested with different bathymetries, it is noted that elevations in the bottom, which occur mainly at the mouth of the estuary, may slightly alter upstream water levels and modify the periods of tidal propagation into the estuary. 
Figure 4 - Measured and modelled vertical currents at B1 and B2 control points
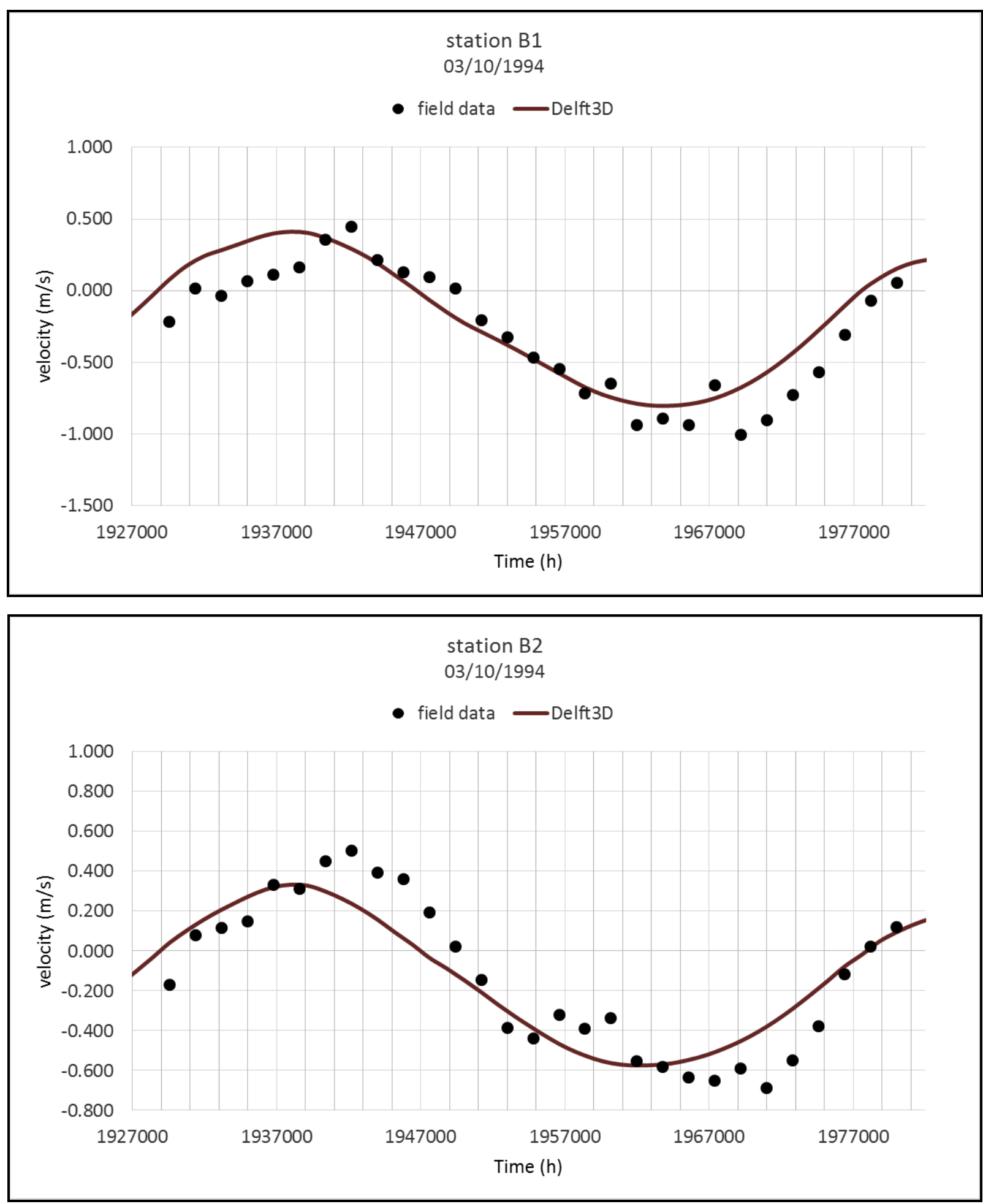

Source: authors, numerical model output

The water level results for the 1966 and 1996 floods are shown in Figures 5 and 6. These simulations were performed considering a constant outflow at Crestuma dam and high and low tide water levels at the ocean boundary. The results obtained 
for these simulations revealed that the simulated water level elevations are in agreement with the measured flood marks. Results of the simulations, involving high and low tide, are very close and almost coincident with the mark of the 1966 flood recorded at D. Luis Bridge, with a slight overestimation of the water level by the numerical model. This fact demonstrates the model's ability to reproduce the dynamics and effects during floods events, showing that the effect of the tide, under these circumstances, is negligible at the estuarine region upstream of the estuary mouth, considering that the D. Luis Bridge is located $5 \mathrm{~km}$ upstream the mouth. Results of the 1966 flood simulation, when compared to the Sandeman and Pina floods, are conservative with respect to water levels for the high and low tide scenarios. The 1996 river discharge was $28 \%$ lower than the one presented during the 1966 flood and, consequently, small differences arise between both simulations regarding the water levels for high and low tide scenarios.

Figure 5 - Maximum measured and simulated water levels at D. Luis Bridge, 1966 flood

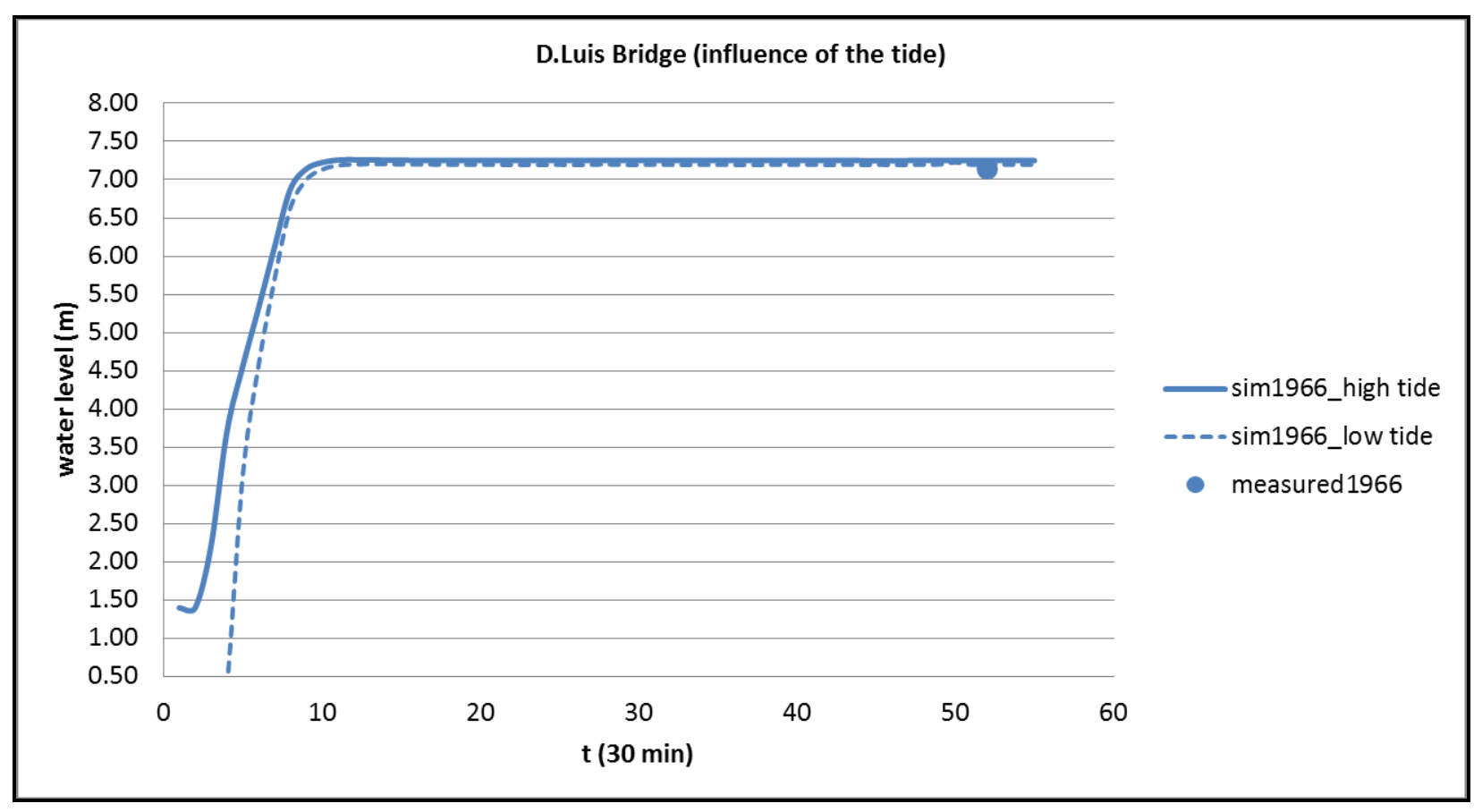

Source: authors, numerical model output 
Figure 6 - Maximum measured and simulated water levels at Sandeman and Pina buildings, 1966 and 1996 floods
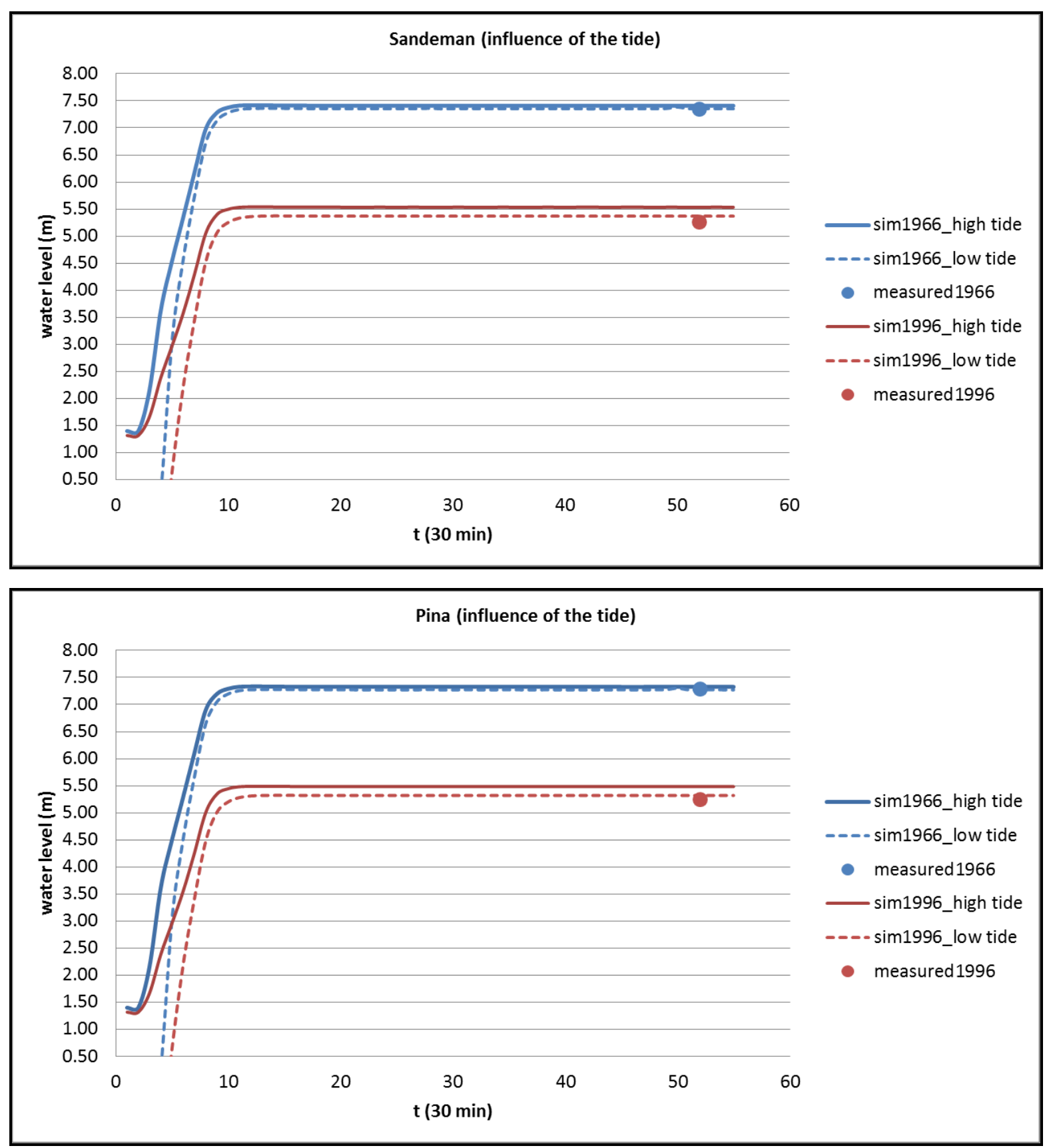

Source: authors, numerical model output

This difference suggested a slight influence of the oceanic water levels in interior zones of the estuary when 1996 river discharges are considered. With respect to the 1996 flood simulations, there is a discrete overestimation of the 
model during high tide, nevertheless, the results are very close of the measured marks for the low tide scenario.

The 2016 flood modelling results and the measured water levels at Cais dos Banhos are shown in Figure 7.

Figure 7 - Measured and simulated water levels at Cais dos Banhos, 2016 flood

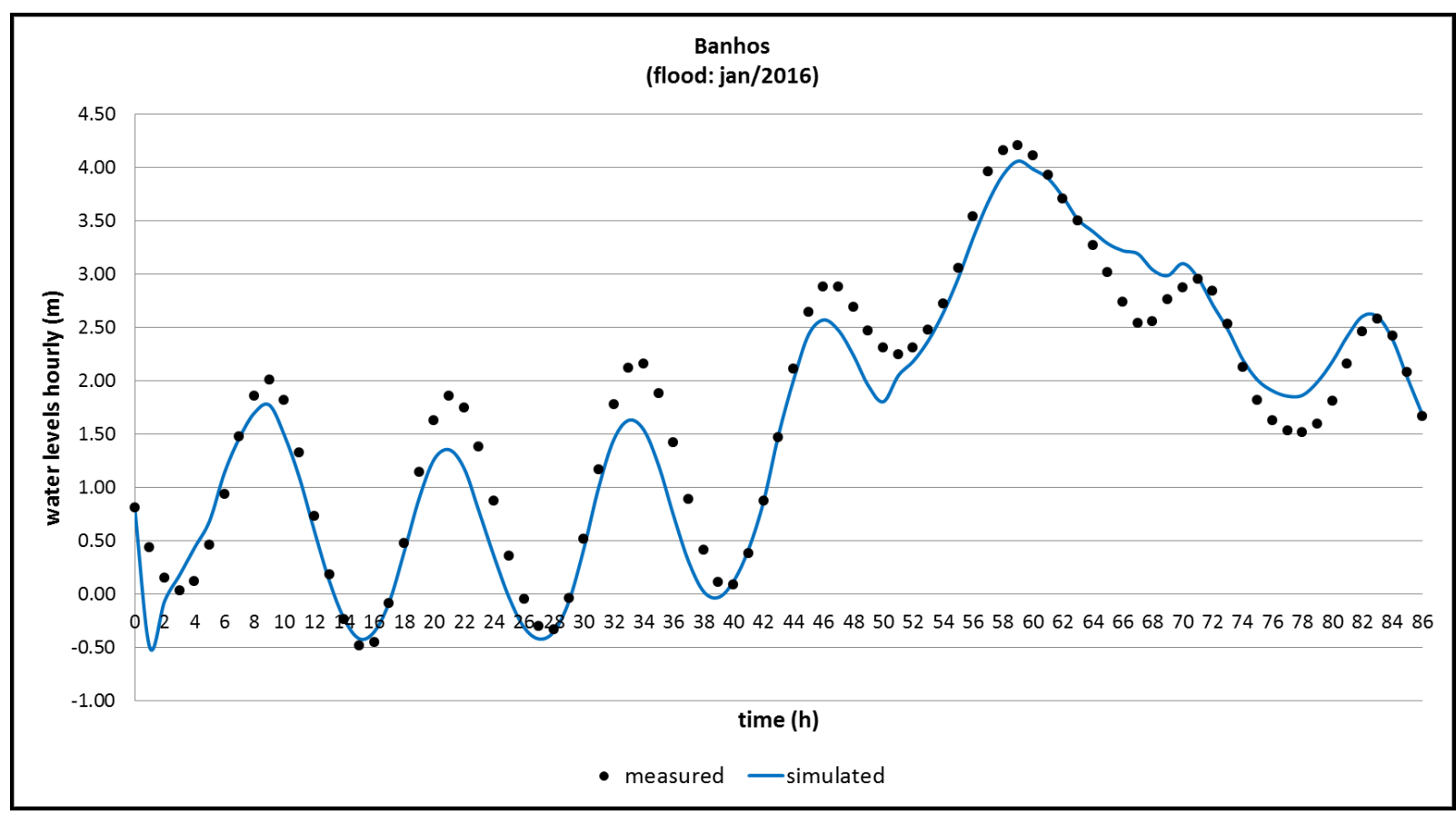

Source: authors, numerical model output

The Figure 7 represents a strong increase of the water level between $48 \mathrm{~h}$ and $60 \mathrm{~h}$ (simulation time) associated with the opening of the floodgates in Crestuma dam due to the flood event that had a peak discharge of $7.200 \mathrm{~m}^{3} / \mathrm{s}$. The water levels simulated at Cais dos Banhos are close to the measured ones mainly during the peak flood period, demonstrating a satisfactory behavior of the implemented numerical model for strong changes of river flow. There is also an agreement between the measured and simulated peak flood time. However, systematic differences appear between measured and simulated water levels during higher and lower water levels periods, probably associated with changes in the bathymetry and in the morphology of the Cabedelo sand spit that were not considered in the numerical grid, and eventual mean sea level oscillations or storm surges that were 
neglected in the simulations. These factors lead into an underestimation of water levels by the numerical model. A lag between the simulated and measured maximum and minimum values was also obtained, as can be observed in the results that precede the maximum peak of the 2016 flood. However, even for a maximum flow rate that is $56 \%$ lower than the full flood volume of 1966 , these previously mentioned factors not taken into account in the simulation, were not of decisive importance for the good approximation between measured and simulated water levels. This fact can be observed in the hydrograph of the period that results in the maximum water level of the 2016 flood. The correlation between measured and simulated water levels in this period (between $52 \mathrm{~h}$ and $60 \mathrm{~h}$ ) was 0,986 , while for the entire period (between $0 \mathrm{~h}$ and $60 \mathrm{~h}$ ) was 0,972. The analysis of the 1966, 1996 and 2016 floods allowed to identify that the bathymetric factor can have a small effect in the estuarine water levels when high river discharges scenarios are represented.

In order to analyze the breakwater influence on the water levels during flood events, a water level profile was represented between the estuary mouth and the D. Luis Bridge, for all the considered floods (1966, 1996 and 2016) and for the two grids (with and without breakwater). The results, depicted in the Figure 8, show the impact of the breakwater in the water level for peak river flows associated with the considered floods. The presence of the breakwater at the mouth promotes an increase of water levels for the entirely profile, with a stronger increase at the mouth and a smaller increase $5 \mathrm{~km}$ upstream of this location. For the 1966 flood (river discharge of $14.600 \mathrm{~m}^{3} / \mathrm{s}$ ) and 1996 (river discharge of $10.500 \mathrm{~m}^{3} / \mathrm{s}$ ) differences in water levels reached $1,70 \mathrm{~m}$ and $0,80 \mathrm{~m}$, respectively, with an increase at $\mathrm{D}$. Luis Bridge for both simulations of the order of $0,50 \mathrm{~m}$. 
Figure 8 - Water level profiles along the estuary considering pre-breakwater and postbreakwater conditions for the 1966, 1996 and 2016 floods

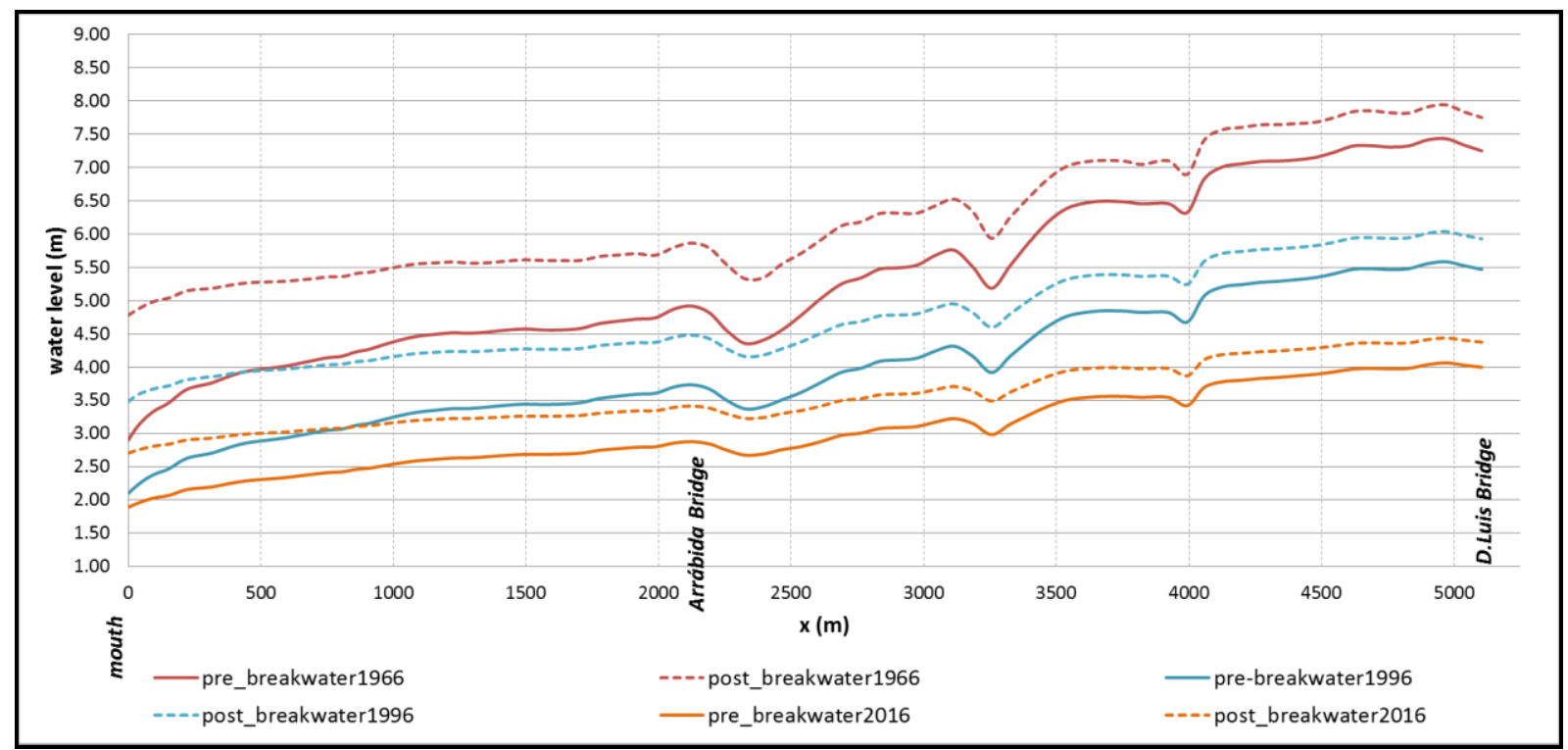

Source: authors, numerical model output

For the 2016 flood (river discharge of $7.200 \mathrm{~m}^{3} / \mathrm{s}$ ) it is noted that the breakwater induces a increment of the water level at the Arrábida Bridge of the order of $0,70 \mathrm{~m}$ and at D. Luis Bridge of $0,40 \mathrm{~m}$. The order of magnitude of the obtained differences in the water levels is significant, especially when considering the expansion of the flooded area and also the associated possible inundation damages. It can be also observed that the impact of the breakwater on the estuarine water level elevation is strongest between the mouth and the Arrábida Bridge rather than at upstream locations.

\section{Conclusions}

The hydrodynamic model implemented in this work for the Douro estuary presented a high degree of robustness when compared with the measured datasets. Both, flood and non-flood simulations presented satisfactory results when compared with water level and velocity currents in-situ measurements, corroborating the 
adequate representation of the dynamic patters of this estuary region and confirming the model ability in reproducing the water levels associated with flood events. The model also presented an adequate behavior when strong changes of river flow are introduced into the forcing datasets. Nevertheless, the differences between the measured and the modelled values could be related with inaccuracy in the field measurements, changes in the bathymetry and in the morphology of the estuarine sand spit that were not considered in the numerical grid, and eventual mean sea level oscillations, sea lever rise, wave set-up or storm surges that were neglected in the simulations.

These factors may explain the underestimation of flood levels, simulated by the numerical model for the 2016 event when compared to measured levels at Cais dos Banhos monitoring station. However, it could be verified that even for long periods, the simulated water levels have a good approximation with the flood levels of historical events. This demonstrates the modelling system capabilities to perform numerical analyzes of water levels with fixed bottom, with low computational costs, which is important for model use in a forecast platform.

This work allowed to represent some dynamical aspects of this estuarine region. It was demonstrated that the Douro estuary is a river dominated estuary under flood conditions. Nevertheless, there is a slightly effect of the tide for the lower river flows represented (1996 flood). Another important aspect of this estuarine region is the presence of the breakwater at the mouth. It was demonstrated that this breakwater promotes an increase of the estuarine water levels during flood events, with a stronger increase at the mouth and a smaller increase $5 \mathrm{~km}$ upstream of this location. This means that future floods in this estuary region can have harmful effects over the margins, being a risk for the population and structures and dealing into economic losses.

An aspect that must be evaluated in future works is related with the sand spit evolution after the breakwaters construction. Besides eventual environment impacts resulting from local siltation, this feature may directly interfere with estuary flood levels, especially in the estuary mouth-zone. So future works will take into 
consideration the evolution of this sand spit and its effects over the water levels during flood events.

The good results obtained with the numerical simulation of the estuary for the specific flood scenarios show that there is a viable and realistic possibility of long-term modeling to support the management process of estuary flood levels.

\section{Acknowledgments}

This research was partially supported by the Research Line ECOSERVICES, integrated in the Structured Program of R\&D\&I INNOVMAR: Innovation and Sustainability in the Management and Exploitation of Marine Resources (NORTE-010145-FEDER-000035), funded by the Northern Regional Operational Programme (NORTE2020) through the European Regional Development Fund (ERDF), and by the Brazilian National Council for Scientific and Technological Development (CNPq) through a scholarship granted to the 1st author (Process 200016 / 2014-8).

\section{References}

ABUBAKER E. AND WALID E. 2015. Hydrodynamic evaluation of long term impacts of climate change and coastal effluents in the Arabian Gulf. Marine Pollution Bulletin. v.101, issue $2,667-685$.

ALLARD R., DYKES J., HSU Y.L., KAIHATU J., CONLEY D. 2008. A real-time nearshore wave and current prediction system. J. Mar. Syst. 69, 37-58.

APA. 2015. Hydrographic Region Management Plan 2016/2021. Part I - Framework and General Aspects. Douro Hydrographic Region (RH3). Portuguese Environment Agency

ARAÚJO, MAVC, MAZZOLARI, A, TRIGO-TEIXEIRA, A. 2013. An object oriented mesh generator: application to flooding in the Douro estuary. Journal of Coastal Research, Special Issue 65: 642-647.

AZEVEDO, IC, DUARTE, PM, BORDALO, AA. 2008. Understanding spatial and temporal dynamics of key environmental characteristics in a mesotidal Atlantic estuary (Douro, NW Portugal). Estuarine, Coastal and Shelf Science 76: 620-633. 
AZEVEDO, IC, BORDALO, AA, DUARTE, PM. 2010. Influence of river discharge patterns on the hydrodynamics and potential contaminant dispersion in the Douro estuary (Portugal). Water Research 44: 3133-3146.

BASTOS, L, BIO, A, PINHO, JLS, GRANJA, H, SILVA, A.J. 2012. Dynamics of the Douro estuary sand spit before and after breakwater construction. Estuarine, Coastal and Shelf Science 109: 53-69.

BASTOS, L., A BIO AND I. IGLESIAS 2016. The Importance of Marine Observatories and of RAIA in Particular. Frontiers in Marine Science 3. DOI: 10.3389/fmars.2016.00140.

BENAVENT, M, ARNOSO, J, MONTESINOS, FG. 2009. Regional ocean tide loading modelling around the Iberian Peninsula. Journal of Geodynamics 48:132-137.

BOUMA T.J., VAN DUREN L.A., TEMMERMAN S., CLAVERIE T., BLANCO-GARCIA A., YSEBAERT T., HERMAN P.M.J. 2007. Spatial flow and sedimentation patterns within patches of epibenthic structures: combining field, flume and modelling experiments. Cont. Shelf Res. 27, 1020-1045.

DELFT3D-FLOW, 2011. User Manual - Simulation of multi-dimensional hydrodynamic flows and transport phenomena, including sediments. Deltares, Netherlands. 674p.

GANJU, N.K., SCHOELLHAMER, D.H. 2009. Calibration of an estuarine sediment transport model to sediment fluxes as an intermediate step for simulation of geomorphic evolution. Continental Shelf Research 29, p.148-158.

GÓMEZ-GESTEIRA, M, GIMENO, L, DE CASTRO, M, LORENZO, MN, ALVAREZ, I, NIETO, R, TABOADA, JJ, CRESPO, AJC, RAMOS, AM, IGLESIAS, I, GOMEZ-GESTEIRA, JL, SANTO, FE, BARRIOPEDRO, D, TRIGO, IF. 2011. The state of climate in NW Iberia. Climate Research 48:109-144.

GOMES, MP, PINHO, JL, ANTUNES DO CARMO, JS, SANTOS, L. 2015. Hazard assessment of storm events for The Battery, New York. Ocean \& Coastal Management 118:22-31.

HARCOURT-BALDWIN J.L., DIEDERICKS G.P.J. 2006. Numerical modelling and analysis of temperature controlled density currents in Tomales Bay, California. Est. Coast. Shelf Sci. 66, 417-428.

HU, K., DING, P., WANG, Z. AND YANG, S. 2009. A 2D/3D hydrodynamic and sediment transport model for the Yangtze Estuary, China. Journal of Marine Systems, Vol. 77 No. 1-2, pp. 114-136

KUANG, C., LIU, X., GU, J., GUO, Y., HUANG, S., LIU, S.,YU, W., HUANG, J., SUN, B. 2013. Numerical predictionofmedium-termtidalflatevolutionintheYangtze Estuary: Impacts of the Three Gorges project. Continental Shelf Research, Vol 52, pp. 12-26. 
KWON, J.I., MAA, J.P.Y., LEE, D.Y. 2007. A preliminary implication of the constant erosion rate model to simulate turbidity maximums in the York River, Virginia, USA. Estuarine and Coastal Fine Sediments Dynamics, p.331-354.

LESSER, GR, ROELVINK, JA, VAN KESTER, JATM, Stelling, GS. 2004. Development and validation of a three-dimensional morphological model. Coastal Eng. 51, 883-915.

MAGALHÃES, CM, BORDALO, AA, WIEBE, WJ. 2002. Temporal and spatial patterns of intertidal sediment-water nutrient and oxygen fluxes in the Douro River estuary, Portugal. Marine Ecology Progress Series 233: 55-71.

MENDES, R, VAZ, N, DIAS, JM. 2013. Potential impacts of the mean sea level rise on the hydrodynamics of the Douro river estuary. Journal of Coastal Research, Special Issue 65: 1951-1956.

MUCHA, AP, VASCONCELOS, MTSD, BORDALO, AA. 2003. Macrobenthic community in the Douro estuary: relations with trace metals and natural sediment characteristics. Environmental Pollution 121: 169-180.

MUCHA, AP, BORDALO, AA, VASCONCELOS, MTSD. 2004. Sediment quality in the Douro river estuary based on trace metal contents, macrobenthic community and elutriate sediment toxicity test (ESTT). Journal of Environmental Monitoring 6: 585592.

PARDÉ, M. 1966. Les crues du Douro d'aprés une étude portugaise remarquable. Boletim Trimestral de Informação, Direcção Geral dos Serviços Hidráulicos, Lisboa, n.23, 93-169.

PORTELA, LI. 2008. Sediment transport and morphodynamics of the Douro River estuary. Geo-Marine Letters 28: 77-86.

SANTOSA, SP, MICK, VDW, REYNS, J, ARTHUR, VD, SOLOMATINE, DP, ROELVINK, JA. 2015. Multi station calibration of 3D flexible mesh model: a case study of the Columbia Estuary. Procedia Environmental Sciences. 28, 297-306.

STOSCHEK, O. and Zimmermann, C. 2006. Water Exchange and sedimentation in na estuarine tidal harbor using three-dimensional simulation. Journal of Waterway, Port, Coastal, and Ocean Engineering, ASCE, p.410-414.

TONNON P.K., VAN RIJN L.C., WALSTRA D.J.R. 2007. The morphodynamic modelling of tidal sandwaves on the shoreface. Coastal Eng. 54, 279-296.

VAN MAREN D.S. 2007. Grain size and sediment concentration effects on channel patterns of silt-laden rivers. Sediment. Geol. 202, 297-316. 
VAN MAREN, DS, VAN KESSEL, T, CRONIN, K, SITTONI, L. 2015. The impact of channel deepening and dredging on estuarine sediment concentration. Continental Shelf Research 95: 1-14.

VAN VEN, BAD, VATVANI, D, ZIJL, F. 2015. Tsunami flood modelling for Aceh \& west Sumatra and its application for an early warning system. Continental Shelf Research. 79, 46-53.

VIEIRA, MEC, BORDALO, AA. 2000. The Douro estuary (Portugal): a mesotidal salt wedge. Oceanologica Acta, Vol $23 \mathrm{~N}^{\circ} 5$. 